\title{
6 A Disappearing Planet
}

\begin{abstract}
How lens-based media have confronted the task of recording disappearance, often via ruinous imagery, is the subject of this chapter. I first explore Albert Kahn's Les Archives de la Planète (Archives of the Planet, 1909-1931), a multimedia project whose raison-d'être was the capturing of disappearing realities owing to a sweeping global modernisation. Yet disappearance appears in another, equally significant guise in Kahn's Archive, which contains one of the most exhaustive collections of warfare destruction, as well as films of natural calamities, thus cementing a conception of planetary time as unpredictable rupture. These considerations provide the backdrop for my analysis of contemporary works interested in archiving the planet for a nonhuman future, including Geyrhalter's hybrid fiction-documentary Homo Sapiens (2016) and Trevor Paglen's The Last Pictures (2012) project.
\end{abstract}

Keywords: disappearance, Albert Kahn, ruins, Les Archives de la Planète, Homo Sapiens, The Last Pictures

To exist is to change.

Henri Bergson

We end with planetary imaginaries that have confronted the task of recording vanishing worlds for human and nonhuman futures. As noted in previous chapters, as much as the emergence of indexical media was tied to the promise of revealing novelty and the unseen, it was also inseparable from a quest to capture for posterity humans and nonhuman animals deemed on the verge of extinction. Yet in our time disappearance has gained new, decidedly global contours and dimensions. In the context of climate change, ocean acidification, coastal flooding, deforestation and other anthropogenic disturbances, processes that would normally unfold for humanly

de Luca, T. Planetary Cinema. Film, Media and the Earth. Amsterdam: Amsterdam University Press, 2022 DOI: $10.5117 / 9789463729628 \_$CHO6 
imperceptible periods, if at all, are occurring at an unprecedented rate. Dystopian scenarios anticipated in the near future include the disappearance of entire towns and cities as a result of human-induced erosion and rising sea-rise levels, the Earth's sixth mass extinction, and even the eradication of the conditions that make human life possible on the planet. ${ }^{1}$

Of course, structural inequalities will not merely continue but be exacerbated during some of these scenarios, with poorer countries, regions and peoples likely the first to bear the brunt of disastrous environmental consequences, even if in the long run not even the rich may be spared. As the climate begins to act wildly and unpredictably, from extreme floods through to uncontrollable mega-fires, the idea that the 'end of the world' (meaning: the end of the world for humans) is nigh is no longer sci-fi territory but, as Bruno Latour notes, a global feeling shared by an unprecedented number of human beings inhabiting this Earth right now. ${ }^{2}$ For Anna Lowenhaupt Tsing, it is imperative that we confront the 'terrors of indeterminacy' and our 'current precarity' as 'an earthwide condition': only then will we be able to come up with imaginative strategies of 'collaborative survival' in times of 'economic and ecological ruination'. 3

A cursory glance over recent cultural and knowledge production confirms the prevalence of the trope of the ruin as a signifier of precarious and posthuman times. Bestsellers envisaging The World without Us (Alan Weisman, 2008) and The Uninhabitable Earth (David Wallace-Wells, 2019) now abound, while a number of visual projects have addressed the challenge of figuring a planet depleted of humanity. ${ }^{4}$ In the last sections of this chapter I turn to

1 Stefano Valentino, 'World's Beaches Disappearing due to Climate Crisis', The Guardian (2 March 2020), https://www.theguardian.com/environment/2020/mar/o2/world-sandy-beachesdisappearing-due-to-climate-crisis-study (last accessed 19 September 2020); Christiana Figueres and Tom Rivett-Carnac, “The Only Uncertainty Is How Long We'll Last”: A Worst Case Scenario for the Climate in 2050', The Guardian (15 February 2020), https://www.theguardian.com/environment/2020/feb/15/worst-case-scenario-2050-climate-crisis-future-we-choose-christianafigueres-tom-rivett-carnac (last accessed 19 September 2020); Damian Carrington, 'Earth's Sixth Mass Extinction Event Under Way, Scientists Warn', The Guardian (10 July 2017), https:// www.theguardian.com/environment/2017/jul/10/earths-sixth-mass-extinction-event-alreadyunderway-scientists-warn (last accessed 19 September 2020).

2 Marc Bassets and 'Bruno Latour: “O sentimento de perder o mundo, agora, é coletivo"', El País (31 March 2019), https://brasil.elpais.com/brasil/2019/o3/29/internacional/1553888812_652680. html (last accessed 29 April 2019).

3 Anna Lowenhaupt Tsing, The Mushroom at the End of the World: On the Possibility of Life under Capitalist Ruins (Princeton, NJ, and Oxford: Princeton University Press, 2015), 1, 4, 19.

4 See, for example, Alan Weisman, The World without Us (London: Virgin Books, 2008); Jan Zalasiewicz, with contributions from Kim Freedman, The Earth after Us: What Legacy Will Humans Leave in the Rocks? (New York: Oxford University Press, 2008); David Wallace-Wells, The 
some of these - including the hybrid documentary Homo Sapiens (2016) and the photographic project The Last Pictures (2012) - in order to explore how they imaginatively face the prospect of archiving the world for nonhuman times ahead. I argue that their preservationist impulse to record the planet for the future is symptomatic of a marked sense of temporal disjuncture between an accelerated human time and the deep time of the Earth. But before we get there, I propose we first look at one of the most extraordinary projects in film history designed to fix the present for the future: Albert Kahn's Les Archives de la Planète, or Archives of the Planet (1909-1931). I suggest that Kahn's Archive, which set out to record humanity in the context of a disappearing and volatile world, can provide us with a more historically nuanced lens with which to assess the role of recording media as a visual repository of the planet against the background of temporal indeterminacy, precarity and instability.

As its title indicates, the Archive's ambition was planetary: to record the whole world, its places and its peoples, with the novel technologies available at the time. During its existence over two decades the Archives de la Planète amassed 183,00o metres of film, 72,00o colour photographs, or autochromes, and more than 6,00o stereographs, all taken in over $5^{0}$ countries across four continents. For Kahn, an internationalist and liberal pacifist, the archiving of the world by way of evidentiary media could provide the inhabitants of this planet with the visual proof of human commonality. Yet there was another, equally important goal underwriting the project, the mission of which, in Kahn's own words, was to 'fix, once and for all, the aspects, practices and modes of human activity whose disappearance is but a question of time'..$^{5}$ As Kahn saw it, his Archive was to respond to a sweeping globalisation that threatened local cultures and rural lifestyles, thus safeguarding 'the development of life' at the dawn of the twentieth century 'to the benefit of future Humanity'. ${ }^{6}$ As described by its appointed director, the geographer Jean Brunhes, the Archive, as a 'portrait of real life

Uninhabitable Earth: Life after Warming (New York: The Duggan Books, 2019); Clive Hamilton, Defiant Earth: The Fate of Humans in the Anthropocene (Sydney: Allen \& Unwin, 2017).

5 Kahn, cited in letter from Emanuel de Margerie to Jean Brunhes, reprinted and included in Mariel Jean-Brunhes Delamare and Jeanne Beausoleil, 'Deux témoins de leur temps: Albert Kahn et Jean Brunhes' in Jean Brunhes, autour du monde: regards d'un géographe/regards de la géographie (Boulogne-Billancourt: Musée Albert Kahn, 1992), 91-106; 92, my emphasis. Unless otherwise stated, all translations in this chapter are mine, with precious help from Alastair Phillips and Lúcia Nagib. My thanks to both.

6 Kahn, cited in Paula Amad, Counter-Archive: Film, the Everyday, and Albert Kahn's Archives de la Planète (New York: Columbia University Press, 2010), 149. 
in our time', would 'preserve planetary occurrences that are going to die out' just prior to their vanishing, that is to say, 'while there was still time', as Kahn noted himself. ${ }^{7}$

As I explore below, this resolve to record the world before it changed irrevocably was itself indicative of a historically specific formulation of time as threat. As Philip Rosen has shown, whereas 'pre-Enlightenment historical temporality was not exclusively directional, but reversible, recursive', one of the prevailing conceptions of time in modernity is that it is 'an irreversibly linear, directional stream, any instant of which is unstoppable and unrepeatable. Irreversibility is constant loss, always threatening decay, death, disappearance'. ${ }^{8}$ It is against this background, Rosen explains, that 'a preservative impulse or obsession in the modern West' emerged in the nineteenth century across a number of intellectual and cultural domains, including history, architecture, geology and visual arts. ${ }^{9}$ These gave pride of place to the indexical trace - a crumbling building, a fossil, a historical artefact, a photograph - as the material conduit for a spectator to enter into phenomenological rapport with pastness, often discursively 'converted from death and lifelessness to life: nonbeing is called back into being' ${ }^{10}$ Though Kahn's Archive, which was never public during its time, compiled images for a future spectator, its preservationist credentials must be examined within this prevailing idea of time as a 'threateningly dynamic force'. ${ }^{11}$ The obsessive recourse to figures of life and death made by Kahn and Brunhes are therefore not coincidental but symptomatic: for them, the image was to preserve living phenomena in the context of an irreversibly dissipating reality that could, nonetheless, be relived in the future.

On the other hand, as I also hope to show, the Archives de la Planète contains one of the most exhaustive collections of images of destruction and devastation, that is to say, death. As recent French scholarship on the Archive has emphasised, the outbreak of World War I interrupted its inaugural internationalism, with photographers now dispatched to document a destroyed France in line with Kahn's unconcealed patriotism

7 Jean Brunhes, 'Ethnographie et Géographie humaine', L'Ethnographie: Bulletin de la société d'ethnographie de Paris (1913): 29-40; 38 ; Delamare and Beausoleil, 'Deux témoins de leur temps', 91.

8 Philip Rosen, Change Mummified: Cinema, Historicity, Theory (Minneapolis and London: University of Minnesota Press, 2001), 105, 84-85.

9 Ibid., 6, 46.

10 Ibid., 130.

11 Ibid., xi. 
and the pictures put to the service of propaganda. ${ }^{12}$ In contrast with the films and photographs teeming with human life 'just before' their demise, the war images instead figure disappearance as a perceptually verifiable phenomenon rather than as an invisible temporal force: ruinous buildings and bombed-out towns depleted of human figures. These being ruins formed not through the continuous passage of time but instead the products of mechanised warfare, however, they likewise testify to the Archive's adherence to a modern conception of time as entropic rupture, one that, as my analysis will consider, was also evident in films and photographs of natural calamities produced and acquired by the Archive. In turn, these images of transformation and destruction gain in significance when considered in relation to Brunhes's proto-ecological 'human geography', which, by focusing on the reciprocity between human action and the environment, prefigures Anthropocene discourses and concepts in significant ways.

An archive that remained relatively outside the spotlight through much of the twentieth century, the Archives de la Planète saw its cultural and intellectual status change since the late 1990 s both on its native soil and abroad. In France, this was partly due to a number of anthologies published by or in conjunction with the Musée Albert-Kahn (MAK), which administers and disseminates Kahn's projects since $1990 .{ }^{13}$ This includes the digital storage of materials in a database available for researchers - the FAKIR, or Fonds Albert-Kahn Informatisé pour la Recherche - and the museum's opening up to the public. At the time of writing, most autochromes can be viewed and downloaded by anyone, anywhere in the world on the museum's website, while the Kahn films are soon expected to join the photographs. Parallel to this, and no doubt as a response to some of these developments, the Archives de la Planète has received growing scholarly attention, with a number of studies illuminating the project's tensions and contradictions between still and moving images, cosmopolitanism and nationalism, imperialism and universalism. ${ }^{14}$

12 See Valérie Perlès and Anne Singaud (eds.) Réalités (In)Visibles: Autour d'Albert Kahn, les archives de la Grande Guerre (Paris: Musée départemental Albert-Kahn, Bernard Chaveau Édition, 2019); Isabelle Marinone (ed.) Un monde et son double: Regards sur l'entreprise visuelle des Archives de la Planète (1919-1931) (Perpignan: Presses Universitaires de Perpignan and Institut Jean Vigo, 2019).

13 This includes Jean Brunhes; and more recently, Albert Kahn, singulier et pluriel (BoulogneBillancourt: Musée départemental Albert-Kahn, 2015); Valérie Perlès with Manon Demurger (eds.) Les Archives de la Planète (Paris and Boulogne-Billancourt: Musée départemental Albert-Kahn and Lienart, 2019).

14 Teresa Castro, La pensée cartographique des images: Cinéma et culture visuelle, (Lyon: Aléas Éditeur, 2011); Jay Winter, Dreams of Peace and Freedom: Utopian Moments in the 2oth Century (New 
In particular, Paula Amad's indispensable book-length study, CounterArchive: Film, the Everyday and the Archives de la Planète (2010), has argued for the centrality of the concept of the everyday to account for Kahn's Archive. Looking predominantly at the film collection, Amad argues that the Archive's impetus to 'record and store the raw data of routine experience, transient details, uneventful moments, ordinary gestures, and casual occurrences' furnished it with the potential to destabilise from within the notion of the archive understood as a positivist apparatus of historicist knowledge. ${ }^{15}$ As she notes: 'the uniqueness of [Kahn's] films resides in their capturing of the spatial and temporal webs of daily life - eating, working, playing, walking, reading' - ordinary moments that unsettled traditional epistemologies of history understood as the concatenation of significant happenings. ${ }^{16}$ Yet Amad knows she is treading on precarious ground, since as she herself admits, Kahn's Archive is in fact teeming with milestone historical events, meaning the everyday life on show in the films is not 'separate from or neatly opposed to political or economic history.' ${ }^{17}$ Just as importantly, as she also notes, the Archive is 'based on a profound sense of the afterlife of the planet, or more precisely, the apocalyptic feeling about the world that existed as it entered and exited the First World War'. ${ }^{18}$

With its connotations of mundanity, uneventfulness and repetition, the everyday is therefore, in my view, insufficient in itself to account for the tumultuous background against which quotidian life often unfolded in Kahn's films and autochromes. Accordingly, I want to suggest that if the everyday is to remain a useful category for examining the Archive, then we might need to recruit the help of its conceptual opposite and frame it as the oxymoron 'extraordinary everydayness', or 'ordinary life in extraordinary times' - to borrow the subtitle of Sheila Fitzpatrick's book on Soviet life in the 1930 . ${ }^{19}$ My hope in doing so is to home in on the idea

Haven, CT, and London: Yale University Press, 2006), 11-27; Katherine Groo, Bad Film Histories: Ethnography and the Early Archive (Minneapolis and London: University of Minnesota Press, 2019), 43-104; Trond Lundermo, "The Archives of the Planet" and Montage: The Movement of the Crowd and "the Rhythm of Life"' in Eivind Røssaak (ed.) Between Stillness and Motion: Film, Photography, Algorithms (Amsterdam: Amsterdam University Press, 2011), 207-224; Trond Erik Bjorli and Kjetil Ansgar Jacobsen (eds.) Cosmopolitics of the Camera: Albert Kahn's Archives of the Planet (London: Intellect, 2020).

15 Amad, Counter-Archive, 5 .

16 Ibid., 9 .

17 Ibid.

18 Ibid., 23 .

19 Sheila Fitzpatrick, Everyday Stalinism: Ordinary Life in Extraordinary Times: Soviet Russia in the 1930s (New York: Oxford University Press, 2000), 1, 2. 
of disappearance underwriting the Archive and to demonstrate that its obsession with recording perishable phenomena was variously visualised and negotiated alongside categories of disturbance, turbulence, upheaval, disruption, catastrophe and turmoil: sociopolitical and environmental, natural and human induced. Given the Archive's monumentally heterogeneous holdings, the following is a brief, modest and, in some places, even arbitrary analysis. Yet I hope to show that the sense of planetarity formulated by the Archive via human geography cannot be dissociated from ideas of precarity, instability and temporal variability, which asks us to reconsider the current doxa that these categories are exclusive to our time as a global condition.

\section{A Human Planet}

Albert Kahn was born Abraham Kahn in 186o in Alsace, northeastern France. Following the Franco-Prussian War in 1871 and the annexation of Alsace-Lorraine to Germany, Kahn's Jewish family opted for French citizenship and Kahn moved to Paris at the age of 16 . There he began his career as a bank clerk and eventually became a trader on the foreign stock market. Over 20 years Kahn amassed a sizeable fortune by speculating on emerging markets, especially gold and diamond mining in South Africa. Astonishingly, by 1897 Kahn was the owner of his own bank, investing in Japan through international loans while working as a financier and economic adviser in the Japanese Imperial Court.

Kahn harboured ambitions other than finance, however. As a result of his growing fortune, he designed and supported a number of projects with utopian and cosmopolitan aspirations, including: a garden at the back of his mansion on the outskirts of Paris in Boulogne-Billancourt, today open to the public, which combines plants, soils and ornaments from different parts of the world; the Autour du Monde (Around the World) scholarships, founded in 1898 , which awarded male (and later female) students grants to travel abroad and whose cosmopolitan foundations formed the basis of the Société Autour du Monde (Around the World Society, 19o6-1949); and the Comité National d'Études Sociales et Politiques (National Committee for Social and Political Studies, CNESP, 1916-1931), the aim of which was to foster international political and economic collaborations.

The Archives de la Planète must therefore be seen as one, though certainly crucial, branch of an interconnected web of projects that promoted global 
thinking and instigated transnational debate, exchange and cooperation. ${ }^{20}$ No doubt Kahn's cosmopolitanism was in some measure informed by the imperial imaginary prevailing in the France of his time, and while the Archive itself was never a colonial enterprise, it benefitted from the structures and networks of colonialism; indeed, the largest portion of the countries recorded by Kahn's operators were French colonies or connections. ${ }^{21}$ As Jay Winter summarises: though 'Kahn never succumbed to simple racial stereotypes', in the end he 'was a French republican imperialist, and could not escape the contradictions in the ideas he held, ${ }^{22}$ As we shall see, such contradictions came into particularly sharp relief as soon as the war broke out.

It is worth mentioning that Kahn was also a close friend of the French philosopher Henri Bergson, whom he met while taking philosophy classes just after moving to Paris. The confluences between Bergson's ideas and Kahn's Archive are well documented. ${ }^{23}$ Here I want to simply draw attention to Bergson's well-known concept of durational flow - or durée - as yet one more manifestation of what Rosen defines as a specifically 'modern conception of historical temporality' noted earlier. ${ }^{24}$ Indeed, one would be forgiven for assuming that Rosen is quoting in full Bergson's theory of Creative Evolution (as per his 1907 book) when he mentions that, for modern historicity, 'life becomes a process of unending transition to a different future, for the present is the perpetual change of old into new'. ${ }^{25}$ In response to modernity's wholesale rationalisation of time, Bergson proposed the idea of a qualitative, indivisible duration as the motor of life (élan vital): 'a

20 For an overview of these different projects and how they interconnected and resonated with each other, see Anne Sigaud, 'The Archives of the Planet: Between Cosmopolitanism and Patriotism' in Cosmopolitics of the Camera, 178-205. My thanks to Sigaud for sharing her chapter with me before publication.

21 See Sigaud, 'The Archives of the Planet'; Paula Amad, 'Experimental Cosmopolitanism: The Limits of Autour du Monde-ism in the Kahn Archive' in Cosmopolitics of the Camera, 133-154. 22 Jay Winter, 'Pacifist Photography: Seeing the Face of Humanity' in Cosmopolitics of the Camera, 116-132; 117 .

23 See Sophie Coeuré and Frédéric Worms (eds.) Henri Bergson et Albert Kahn, Correspondances (Strasbourg and Bolougne: Desmaret/Musée départemental Albert-Kahn, 2003); Kjetil Ansgar Jacobsen, 'Henri Bergson and Albert Kahn: The Cosmopolitan Method', Cosmopolitics of the Camera, 206-235; Kjetil Ansgar Jacobsen, 'Bergson's Aesthetics? Autochroming a World of Memories' in Cosmopolitics of the Camera, 261-291; Amad, Counter-Archive, 96-132; Winter, Dreams of Peace, 18-19.

24 Rosen, Change Mummified, 106.

25 Ibid. It is curious that Rosen mentions Bergson in passing only once in his study, not only because Bergson constitutes a major influence on Bazin's formulation of time but also because Bergson's durée was itself a symptom of the nineteenth-century conception of temporality which is the focus of Rosen's book. 
history that is gradually unfolding. ${ }^{26}$ He noted that temporal 'succession is an undeniable fact, even in the material world' and as such, organic and inorganic entities cannot sidestep 'the irreversibility of time'. ${ }^{27}$

Though perhaps with an added dose of anxiety, Bergson's universal temporalisation of reality informed Brunhes's human geography and the Kahn Archive in their battle against time to capture vanishing phenomena. Yet unlike the philosopher, who famously decried recording media due to their transfiguration of the ever-dynamic élan vital - 'the continual change of form' - into immobile snapshots, Kahn and Brunhes had no qualms about regarding the same media as the perfect means by which to preserve life as a soon-to-be past that could be relived indefinitely in the future. ${ }^{28}$

The origins of the Archives de la Planète hark back to a round-theworld trip on which Kahn embarked with his chauffeur Albert Dutertre in 1908-1909, which covered the United States (notably New York and San Francisco), Japan, China, Singapore, Sri Lanka and Italy. Dutertre documented the trip via film, photography and especially stereography, the last a popular recording medium among travellers at the time due to its small plate sizes, which required little light input and short exposure times. ${ }^{29}$ Upon his return, Kahn hired his first professional camera operators: Stéphane Passet and Auguste Léon, the last a former postcard photographer who subsequently accompanied Kahn on a two-month trip to South America in 1909. Stereography was dropped as the medium of choice in favour of the autochrome, an expensive colour photography that used plates coated with dyed starch grains. Patented and commercialised by the Lumière brothers in 1907, the autochrome required an atypically lengthy exposure time, which, as seen in the Kahn picture collection, made it suitable only for immobile objects and required individuals to pose for the camera for long periods so as to prevent blurs.

The official beginnings of the Archives de la Planète, however, coincide with the appointment of Jean Brunhes as its director in 1912. In exchange for accepting the role, Brunhes, a disciple of Paul Vidal de la Blache's 'human geography', was given a Chair at the Collège de France, personally funded by Kahn himself. Film was then recruited as the twin recording technology of the project to compensate for the autochrome's inability to capture and

26 Henri Bergson, Creative Evolution, trans. Arthur Mitchell (New York: Random House, 1944), 9.

27 Ibid., 12, 21.

28 Ibid., 328 , emphasis in original.

29 See Michel Poivert, 'Les yeux d'Albert Kahn: les photographies d'Albert Dutertre durant le voyage autour du monde (1908-1909)' in Les Archives de la Planète, 358-373. 
inhibition of motion. Kahn's initial idea for the role of director was the physical geographer Emmanuel de Margerie, who, when approached, suggested Brunhes given his use of photography as a geographical tool for empirical and field observation, as seen in publications such as Human Geography (La Géographie humaine, 1911) and Photographic Atlas of Terrestrial Relief Forms (L'Atlas photographique des formes du relief terrestre, 1908-1914). As de Margerie confided to Brunhes, he had been sure to show Kahn the latter book and to tell him that, in the field of photography, Brunhes was a 'highly experienced practitioner and, moreover, a friend of Mr. Gaumont' (founder of the film company)..$^{30}$ De Margerie added: 'it is above all the living and human element that interests [Kahn]', thus emphasising the 'ethnographic [as opposed to geographic] dimension' of the project, even if, he concluded, Brunhes should 'banish all fears' and accept the invitation. ${ }^{3}$

In some important ways, however, the 'living and human element' was already a substratum of Brunhes's own human geography, although, admittedly, that discipline was more concerned with human traces on the Earth's crust than with humans themselves. Already in the first edition of Human Geography, Brunhes invites the reader to 'go up some hundreds of yards above the earth in a balloon or an aeroplane, somewhat after the fashion envisaged by the Swiss [sic] geologist Suess at the beginning of his great book The Face of the Earth' $3^{32}$ Brunhes goes on: 'From this imaginary point what shall we see? Or, better still, what are the human facts that a photographic plate would register just as well as the retina of the eye?'.33 As Jeanne Haffner has shown, in the first decades of the twentieth century, aerial photography was embraced by an array of disciplines such as social sciences, architecture, history, ethnography and human geography thanks to 'its promise to offer new insight into the study of humankind and its relationship to the environment'. ${ }^{34}$ In this context, as Marie-Claire Robic notes, Brunhes's approach must be viewed within an 'ecological' rather than 'chorological' French geographical tradition, one that 'inscribed geography in the problematic of the interaction between the biosphere and the physical environment', and attempted to measure "the traces of man" on the face

Delamare and Beausoleil, 'Deux témoins de leur temps', 92.

Ibid., 92.

32 Eduard Suess was Austrian. Jean Brunhes, Human Geography, abridged edition, trans. Ernest

F. Row (London: George G. Harrap, 1952), 36.

33 Ibid.

34 Jeanne Haffner, The View from Above: The Science of Social Space (Cambridge, MA, and London: MIT Press, 2013), 20-21. 
of the earth': 'the destruction of nature, the attacks on the integrity of the planet'.35

Brunhes's geographical programme anticipated two underlying principles of the Kahn Archive. The first is the Bergsonian temporal postulate that both human and physical forces are mutually reinforcing in a state of perpetual change' $3^{6}$ Brunhes writes: 'there is constant progress and recession [...] human phenomena, like all terrestrial phenomena, never remain the same' ${ }^{37}$ In fact, as Robic notes, the idea to record the force of time on material reality goes back to Brunhes's early work on the morphogenesis of rivers and water flows, as well as his study of 'perishable forms' in human habitation as 'the mark of the ephemeral' $3^{8}$ These included 'swiftly abandoned earthen ruins' and 'the gradual disappearance of wooden structures', both of which he recorded when travelling through Egypt in 1897-1899. ${ }^{39}$

Second, human geography's axiom of global interconnection prefigured the Archive's planetary aspirations. Brunhes notes: 'It is not enough to study separately various set of phenomena, for they are not really separate: they are closely connected with one another'. ${ }^{40}$ Here, it is 'the great savant, observer, and innovator Alexander von Humboldt', discussed in chapter 1, that looms large as an influence. ${ }^{41}$ Brunhes speaks of the planet in the Humboldtian sense of 'a system of harmonious order', 'the close interdependence of the different parts of the earth', and 'the concept of the "terrestrial whole", or the unity of the entire globe'. ${ }^{42}$ As Brunhes saw it, human geography's intervention in this field was to place a greater emphasis on human actions as 'part of a wider whole' in terms of a dynamic interaction between human and geographical elements: 'we are entitled and obliged to add to those material forces which we have seen continually in action this new force, not entirely of a material nature, though it shows itself in material effects - the force of human activity'. 43

35 Marie-Claire Robic, 'La géographie dans le mouvement scientifique' in Jean Brunhes, 52-65; 56,64 .

36 Brunhes, Human Geography, 20.

37 Ibid.

38 Marie-Claire Robic, 'Administrer la preuve par l'image: géographie physique et géographie humaine' in Jean Brunhes, 221-233; 229; Marie-Claire Robic, 'Un laboratoire: l'Egypte' in Jean Brunhes, $164-180 ; 175$.

39 Robic, 'Administrer la preuve par l'image', 229.

40 Brunhes, Human Geography, 23.

41 Ibid., 26.

42 Ibid., 21, 26.

43 Ibid., 28. 


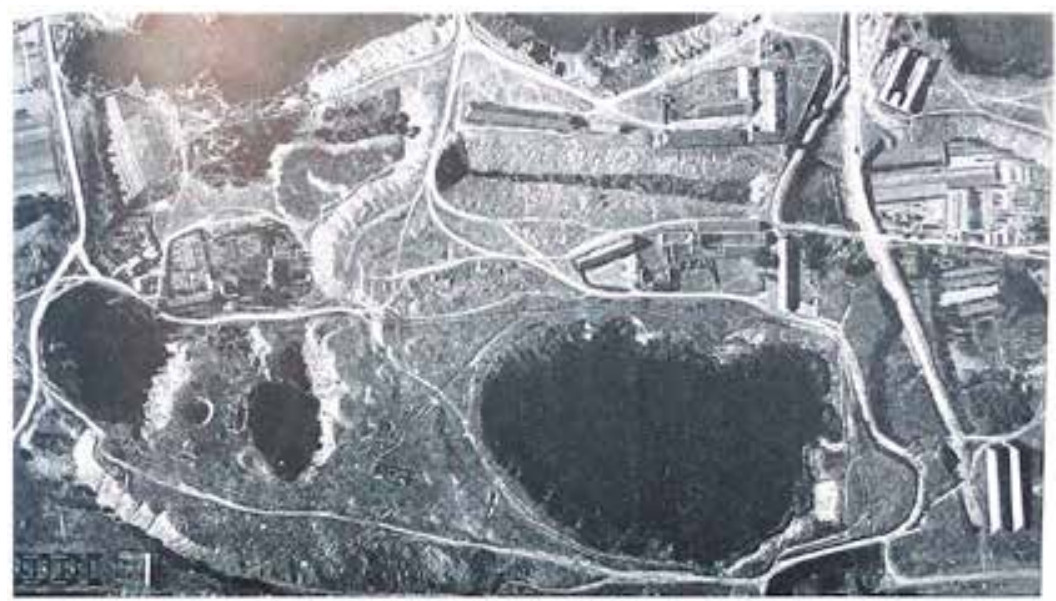

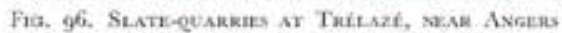

Man' expleitation of minerals is marbed by great holes in the carth - the mines they dig, the oil-wells they lore, and the quarrie tbey mork. Hese are seca the gaping holes made by the extraction of sate. Man

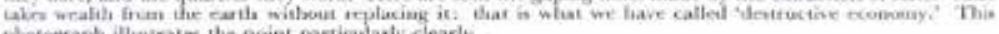
photograpt illeutrates the poist particulasty clearly.

\section{[Sirm xhe wht]}

Figure 6.1 Aerial view of a 'gaping hole' in Human Geography bears an uncanny resemblance to contemporary environmental imagery, as seen in Earth (2019) discussed in chapter 1 (figure 1.6). Image reproduced from item held at the British Library.

It is hard not to think of current Anthropocene discourses when reading these lines, even if one must be wary of anachronisms and remember that the geological periodicity of the Anthropocene as a scientific designation is obviously missing in Brunhes's proto-ecological explorations of the relationship between humankind and the planet. Moreover, as Trond Erik Bjorli and Kjetil Ansgar Jakobsen note, Brunhes distinguished between 'nature as such [including glaciers and the atmosphere] and nature as product of human action', a distinction which, according to the Anthropocene, is no longer tenable given that human action is now widely considered a natural force in a geological sense. ${ }^{44}$ Nevertheless, in its levelling out of geophysical, morphological and human phenomena as reciprocally influential and coconstitutive, human geography prefigures Anthropocene tropes, concepts and figures in important ways.

Brunhes classified human activities on the Earth according to three criteria: 'A) those connected with the unproductive occupation of the soil', such as the construction of houses and highways; 'B) things connected with the conquest of the plant and animal worlds', such as the cultivation of fields

44 Trond Erik Bjorli and Kjetil Ansgar Jakobsen, 'Introduction' in Cosmopolitics of the Camera, $1-23 ; 16$. 
and the domestication of animals; and finally, 'C) the destructive economy', as seen in 'mineral exploitation', where 'men have removed the stone for their own use, without making any restitution', and the 'destruction of plants and animals', including 'trees cut down, and forests burned'. ${ }^{45}$ In order to illustrate these types of activities, the third edition of Human Geography, published in 1925, makes recourse to a number of panoramic and aerial photographs, some of which uncannily foreshadow contemporary environmental imagery. A case in point is the aerial picture of a slate quarry with 'gaping holes' (figure 6.1), which bears a striking resemblance to the satellite shots opening individual episodes in Geyrhalter's Earth (explored in chapter 1). ${ }^{46}$ Whether through its concern with the dissipation of matter as a result of time's entropic force, or with the degradation of the natural environment as the product of humaninduced change, the world envisaged by human geography was therefore always already disappearing: hence the need for empirical observation and the employment of recording technologies to meet that need.

Yet the Archives de la Planète had a reciprocal impact on Brunhes. Foremost among these, as anticipated by de Margerie, was the ethnographic dimension that Kahn's Archive brought to bear on human geography. ${ }^{47}$ Perhaps in an attempt to justify what might have been regarded as disciplinary promiscuity, in 1913 Brunhes published an article in the journal L'Ethnographie, entitled 'Ethnographie et Géographie humaine', in which he argues that rather than being opposed to each other, both disciplines in fact 'complemented [...] and must help each other' ${ }^{48}$ This conflation allows Brunhes to extend the ecological understanding of 'reciprocal actions between the natural environment and humanity' to the idea of a globalisation that, in tune with Kahn's views, leads to cultural homogenisation and eventually disappearance. ${ }^{49}$ Brunhes writes:

At the moment when, as a result of the intensity and multiplicity of communications, all parts of the universe are violently brought into relation

47 That said, both projects also retained differences in their visual approaches. As Didier Mendibil notes, when compared with the autochromes, the 'framing of the photographs of Human Geography is not as close and the "landscape views" are twice as frequent'. See Didier Mendibil, 'À la recherche de l'effet Brunhes' in Les Archives de la Planète, 130-139; 133. See also Franziska Scheuer, 'Autochromes in Service of Human Geography: Jean Brunhes and the Aesthetics of The Archives of the Planet' in Cosmopolitics of the Camera, 238-26o.

48 Brunhes, 'Ethnographie et Géographie humaine', 32.

49 Ibid. 
with one another, humanity is tending towards a certain uniformity of customs, needs and daily habits. The economic and geographic fact of circulation (the Verkehrskultur, as the Germans say) plays such a predominant role that, in the global competition, the former small economic units which lived their own life, with complete independence, producing roughly all they needed, are facing an increasing threat to their existence on a daily basis and will soon disappear..$^{\circ}$

In this context, Brunhes goes on, the aim of the Archives de la Planète was to establish a 'record of humanity captured in the midst of life at the dawn of the twentieth century'. ${ }^{1}$

On the one hand, Brunhes's repeated invocation of figures of vitalism to describe the Archive is connected with the medium of film, which, thanks to its properties of motion, permits 'an exact and perfect register of that which belongs to the domain of life'. Thus, he goes on, the Archive's aim is to 'to capture and preserve planetary occurrences that are going to die out', thus offering a 'portrait of real life in our time [...] for those who will come after us'. ${ }^{2}$ Whereas ethnographic museums and herbariums displayed work utensils and 'dead plants' cut off from their environments, film enabled these elements to be 'reassembled and brought to life, as they are in reality'. ${ }^{3}$ On the other hand, Brunhes devotes equal attention to the Archive's other medium, the autochrome. He justifies its application on the basis of its 'rigorously exact' rendering of colour (as seen in traditional garments) and the idea that it can capture 'the truth' of human behaviour in their contextual environment, in contrast with the isolated human figures and types in 'wax casts' or 'posed photographs' in ethnographic museums. ${ }^{54}$

It is worth pausing for a moment over Brunhes's reflections. First, his acknowledgement that the Archive is for 'those who will come after us' reveals that it comes into full fruition only when considered from its point of reception, that is, an envisaged spectator in the future. Second, the static autochrome was for him not to be set against the motion picture, for both technologies put life into the reproduction of reality: the one because of movement and the other because of colour. Finally, Brunhes's pejorative allusions to anthropometric photography, wax casts and dead plants evince

54 Ibid., 39. For an analysis of the role of traditional vestments in the Kahn Archive, see Valérie Perlès, 'Les types en costume: de l'ethnologie à la politique' in Les Archives de la Planète, 182-197. 
his concern with situating the Archives de la Planète in what Stephen Bann has defined as 'a continuum of forms of historical representation' in nineteenth-century media culture. For Bann, these forms, which included painting, taxidermy and dioramas, promised 'effects of resurrection' that betrayed a formulation of time as threat. ${ }^{55}$ Whereas tropes of resurrection and afterlife received a new boost with the advent of cinema and were recurrent and even commonplace in early film culture and theory, what is striking in Brunhes's remarks is the self-consciousness with which he locates the Archives de la Planète within a wider cultural history in order to bolster, by contrast, the increased realism of its own films and colour photographs in their vivifying effect..$^{6}$

Yet how was the 'domain of life' visualised, after all, in the Kahn films and photographs? At the project's dawn, a notable concern on Kahn's part was to record rural communities due to the view these were the first to vanish in the age of large-scale industrial capitalism. ${ }^{57}$ Even before Brunhes's appointment, Auguste Léon had been dispatched to villages in rural Sweden and Norway in 1910, with some of the autochromes depicting the country dwellers in local garments posing individually or in groups outside their traditional houses and workplaces. One photograph, for example, shows five women sitting and standing outside the hotel where they worked (online catalogue entry: A286). ${ }^{8}$ Another portrays five children on the stairs of their house, with imposing pillars behind (A458). Bearing in mind the diversity of images in the Kahn Archive, the visual set-up of locals posing frontally outside their homes or workplace, in traditional costume and staring fixedly into the camera is a dominant one across the pictures of peasant life. Given the long exposure required, the autochrome process demanded immobile poses not unlike the earlier daguerreotype, in whose resulting portraits Benjamin detected an 'inhuman, one might even say deadly' quality thanks 'to the (prolonged) looking into the camera'.59 Something similar can be discerned in many of Kahn's autochromes, and their 'deadly quality' gains further significance in the knowledge of what motivated their taking.

55 Stephen Bann, The Clothing of Clio: A Study of the Representation of History in NineteenthCentury Britain and France (New York: Cambridge University Press, 1984), 136.

56 For an account of these tropes, see Amad, Counter-Archive, 139-141.

57 Michel Lesourd, 'Lappropriation du monde' in Jean Brunhes, $15^{-51} ; 3^{6}$.

$5^{8}$ Number in parentheses after films and autochromes throughout this chapter refer to their catalogue entry on the online collection: http://collections.albert-kahn.hauts-de-seine.fr/.

59 Walter Benjamin, Illuminations, trans. Harry Zohn and edited by Hannah Arendt (New York: Shocken Books, 2007), 188. 
In their intimation of a world that had remained unscathed by the forces of modernity, Kahn's images of pastoral life suspended in time recall what Rosen defines as the 'just before' temporality of so-called living history and museum villages in their reconstruction of a rural past that is about to be swept away. Looking at Colonial Williamsburg in Virginia and Greenfield Village in Michigan, conceived by John D. Rockefeller Jr. and Henry Ford respectively in the 1920s, Rosen notes the discrepancy between the 'historical "just before" capitalism figured in these museums and the fact they were supported by 'major industrial and finance capitalists'. For Rosen, this begs analogies with 'the "just before" in Freud's much-cited account of fetishism' as a threatening knowledge that must be continuously averted through recourse to an 'obsessive overvaluing' of an object, in this case the past itself. $^{60}$ The prevalence of pre-industrial temporalities in Kahn's Archive, itself brought to fruition by a finance trader, participates in this problematic and activates similar defensive mechanisms.

However, the Kahn Archive cannot be reduced to its penchant for rurality. Equally prevalent in its holdings is modern, street life captured on film in urban settings, especially Kahn's beloved Paris. Trond Lundermo has examined the prevalence of crowds in the Archive films, which often register the hustle and bustle of cities, or the 'rhythm of life', via static long takes, panoramas and tracking shots. ${ }^{6}$ Indeed, unlike the contemporaneous, highly trimmed 'actualities', the majority of Kahn's films are unpolished rushes that relied on on-camera montage and unbroken shots. In turn, this preference for 'uninterrupted location shooting' has been queried by Amad in terms of a correspondence with 'Bergson's durée réelle (time as human awareness experiences it)', and consequently André Bazin's 'own Bergsonian [...] "cinema of la durée"'. ${ }^{2}$ For Amad, however, 'the idea that Kahn's films somehow materialize the continuity of la durée' must be approached with caution, given that 'they focused just as much on newly emerging rhythms, ruptures, and experiences specific to modernity as on the inevitable disappearance of more traditional modes and practices of human activity'. ${ }^{6}$

And yet, from a different angle this dual focus does not so much attest to a dichotomy as evince that, within the Archive's conception of time, both phenomena - the new experience of modernity and the disappearance of

\footnotetext{
60 Rosen, Change Mummified, 71, 73 .

61 Lundermo, “The Archives of the Planet" and Montage', 211-216. See also Teresa Castro, 'Vues panoramiques et travellings: Les Paysages en mouvement des Archives de la Planète' in Les Archives de la Planète, 390-399.

62 Amad, Counter-Archive, 104.

63 Ibid.
} 
traditional cultures - are two sides of the same temporal coin: a 'history that is gradually unfolding', to cite Bergson himself. ${ }^{64}$ In this sense, Bazin's famous definition of film as 'change mummified', according to which 'for the first time, the image of things is likewise the image of their duration', is a useful concept to bear in mind. ${ }^{65}$ As Rosen has shown, for Bazin, 'reality is definitionally temporalized, in the sense that it always involves change', a foundation of his theory that must be treated itself historically, that is to say, in the context of 'a preservative impulse or obsession in the modern West' that started to gain traction in the nineteenth century. ${ }^{66}$ In many ways, the Archive was both part and parcel of this impulse to capture change as it happened in flux, and both Kahn and Brunhes agreed on the 'urgency of the work to be accomplished' in order to safeguard 'the memory of a reality in the process of disappearing, ${ }^{67}$

This urgency resulted not only from technological transformations but also from a sense of instability related to continuous war and a rapidly changing world order. As Winter argues, Kahn's liberal brand of internationalism, according to which peace was the precondition for free trade, cannot be dissociated from a 'backdrop of worldwide violence', with the 'decade from 1895 to $1905\left[\right.$ [...] marked by armed conflict in every continent'. ${ }^{6}$ At the same time, Kahn's awareness that 'the machinery of progress [could] all too easily become engines of destruction and disaster' meant that it was imperative to record geographic areas on the brink of cataclysmic sociopolitical change, as proved by the Archive's first missions under Brunhes's direction. ${ }^{69}$

In 1912 Passet was dispatched to China and Morocco, the former because of the rise of the nationalist movement of Sun Yat-sen, the latter due to the fact it had become a French protectorate..$^{70}$ In that same year Brunhes himself travelled to Bosnia-Herzegovina in his first mission with Léon and in May 1913 to Macedonia, a few months prior to the outbreak of the second Balkan war. The aim of these missions was to document the ethnic diversity of the region before it was too late, as nationalist factions had begun to scramble for sovereignty. The resulting autochromes, which were used in

64 Bergson, Creative Evolution, 9.

65 André Bazin, What is Cinema?, volume 1, trans. and edited by Hugh Gray (Berkeley, Los Angeles and London: University of California Press, 2005), 15.

66 Rosen, Change Mummified, 6, 46.

67 As noted by Marie Bonhomme (with Mariel Jean-Brunhes Delamarre), 'Le champ du monde' in Jean Brunhes, 181-194; 181.

68 Winter, Dreams of Peace, 12.

69 Ibid., 18.

70 Bonhomme, 'Le champ du monde', 182. 
Brunhes's first illustrated lectures at the Collège de France and attested to the co-existence of peasant Muslims, Jews and Christians, soon became visual records of a reality that vanished months after the moment of its registration.

As soon as the war ended, it was Passet's turn to travel to the region, in September 1913, to document the ravaged countryside and the displacement of thousands of Muslims. One especially poignant picture, taken in today's Bulgaria, shows a group of women, some carrying babies, posing for the camera amid the rubble, with only the skeleton of a house in the background, two thin walls barely standing (A3904). Other films and autochromes document a nefarious refugee camp near Salonika: wooden carts, covered with rags, turned into makeshift houses ( $\mathrm{A}_{3} 847$ ); a man drinking a cup of coffee seated on the ground ( $\left.\mathrm{A}_{3} 863\right)$; a woman cooking on the floor, with blurred children looking into the camera in the background (A3869). Documents of everyday life in unprecedented and deadly times, these images of mundane occurrences against the background of forced displacement and conflict foreshadow the Archive's painstaking coverage of WWI on French soil in the years to come.

\section{An Inhuman Planet}

The Great War constituted a watershed during the Archive's existence. As Valérie Perlès tells us: 'Between 1914 and 1918, 50\% of the production of images was devoted to the war and the subject matter was recurrent until 1930, to the point of representing today $20 \%$ of the entire collection'. ${ }^{11}$ This turn to the national was not inconsequential or neutral, as recent French scholarship (Perlès's work included) has noted in relation to the many roles the Kahn Archive played in generating public support for the Allies. As Anne Sigaud has shown, from December 1914 to August 1916, thanks to Kahn's contacts in the army, nearly 1,500 war-related photographs were produced in missions in northeastern and central France, in two of which Brunhes himself participated and used the pictures in lectures at the Collège de France in order to garner public support against the Germans. ${ }^{72}$ In 1917, Kahn struck a deal with the Section Photographique de l'Armée (SPA), recruiting the army photographers Fernand Cuville and Paul Castelnau,

71 Valérie Perlès, 'Des images pour quoi faire?' in Réalités (In)Visibles, 18-26; 25.

72 Anne Sigaud, 'Entre documentation et propagande: vocation et usage politiques des Archives de la Planète' in Les Archives de la Planète, 280-291; 282. 
who started taking two plates for each autochrome, one for the Archive and the other for the army. ${ }^{73}$

That a pacifist such as Kahn would collaborate with the army and become involved in war propaganda raises some thorny questions, some of which can be illuminated by a pamphlet he wrote between March 1917 and July 1918. Published in December 1918 and entitled Des droits et des devoirs des gouvernements (On the Rights and Duties of Governments), it argued for a supranational federation to safeguard peace for future generations, in many ways prefiguring the creation of the League of Nations (1920), of which Kahn became an ardent enthusiast. As Frédéric Worms has shown, Kahn's manifesto has the imprint of Bergson all over it, both in its rhetorical recourse to vitalist figures and in 'the opposition between France and Germany', which is mapped on to 'an opposition between Spirit and Matter, Life and Death'.74

Whereas Kahn's distress over the war is palpable - 'the storm that shaking the Earth touches every living being' and 'destroyed all dreams of humanity' - humanity itself is measured against the Germans, in turn defined as 'the negation of all morals, of all justice' ${ }^{75} \mathrm{Kahn}$ asks: 'The question we must answer is: will it be the German sword or humanity that will triumph?', then adding: 'For the first time, a group of individuals set their sights on the entire human race; for the first time, all of humanity, at the same time, is threatened with the same fate, a fate that we dare not reveal. ${ }^{6}$ Kahn's allusion to total death formulates a 'negative universalism' that is, paradoxically, segregational from the outset in its exclusion of Germans. ${ }^{77}$ In the following decade, the Archive's cosmopolitan credentials would suffer other blows, with Brunhes increasingly aligned with imperial ideology and interests and Kahn himself embracing some aspects of French colonial expansion by the late $1920 .^{7^{8}}$

73 Anne Sigaud, 'Des Archives de la Planète aux archives de la guerre: "Réalités invisibles, notre raison doit les discerner"' in Réalités (In)Visibles, 30-54; 34; Perlès, 'Des images pour quoi faire?', 23.

74 Frédéric Worms, “Agir en homme de pensée, penser en homme d'action?”: L'action e la pensée de Kahn et Bergson à l'épreuve du siécle' in Henri Bergson et Albert Kahn, 111-126; 120.

75 Albert Kahn, Des droits et des devoirs des gouvernements (Paris: Imprimerie de Vaugirard, 1918), 11.

76 Ibid., 3, 24 .

77 I borrow the term 'negative universalism' from Dipesh Chakrabarty's 'The Climate of History: Four Theses', Critical Inquiry 35: 2 (2009): 197-222; 207.

78 See Marie-Claire Robic, 'Regard géographique et intelligence du monde: Jean Brunhes, la géographie humaine et les Archives de la Planète' in Les Archives de la Planète, 84-96; 93-94; Sigaud, 'Entre documentation et propagande', 284, 286, 288. See also Amad, Counter-Archive, 
In her study of the Archive's involvement in war propaganda, Sigaud points out that the 'photographic motifs are perfectly consistent thematically and stylistically with the numerous illustrations in the contemporaneous pamphlets denouncing the German "barbarism"', with France placed 'in a position of legitimate self-defence against a Germany presented as solely responsible for the war, deliberately destructive'. ${ }^{79}$ Taken with the aim of boosting morale, the war autochromes were put to the service of patriotism, which in turn meant that certain subjects, such as the tens of thousands of corpses produced by warfare, are often nowhere to be found. By the same token, soldiers frequently appear in dignified and pensive positions; in groups denoting camaraderie in the trenches and the camps; or else engaged in quotidian errands: seated at a table having lunch (A005935); sleeping inside a tent (Ao11030); writing in a notebook (A010999) - all photographed during Passet's mission in $1915^{-16} .^{80}$

The majority of the pictures in the war collection, however, are of dilacerated towns and ruinous buildings. These too can be linked to propaganda, given that destroyed national monuments and especially cathedrals played on national and religious sentiment as symbols of French cultural heritage. ${ }^{81}$ Yet, as I explore in the remainder of this section, the prevalence of ruins in the Kahn Archive also begs to be examined in relation to its foundational concept of disappearance, which was now visualised in concrete reality and as the absence of humanity rather than as an invisible temporal force traversing the 'domain of life'. Moreover, these images of destruction are significant when explored next to the films of natural catastrophes acquired and produced by the Kahn Archive, which, I suggest, further confirms its attachment to a conception of time as unpredictable rupture.

To be sure, the Archive's ethos of extraordinary everydayness still prevailed during the war. Many autochromes show residents posing outside their house remnants, and a busy Paris was similarly the sustained object of filmic attention - no doubt, as Teresa Castro has astutely shown, as a way of proclaiming in patriotic mode that life defiantly went on in the capital. ${ }^{82}$

265-268 for an account of Kahn's Archive and its varied if not necessarily direct connections with colonialism.

79 Sigaud, 'Des Archives de la Planète aux archives de la guerre', 38.

8o For an account of the Archive's autochromes from WWI, see also Emmanuelle Danchin, 'The Archives of the Planet and the First World War' in Cosmopolitics of the Camera, 98-113.

81 See Claire Maingon, 'Dans l'oeil de la Grande Guerre: Esthétique et culture visuelle' in Réalités (In)Visibles, 157-167;164.

82 Teresa Castro, 'Le Quotidian est politique: Le cas des films 1914-1918' in Réalités (In)Visibles, 188-192. 
At the same time, human-free landscapes and cityscapes are anything but unusual in the Kahn Archive, many of which can be linked to the precepts and influence of human geography. ${ }^{83}$ Yet the specific configuration of ruins and lack of humanity prevalent in the war pictures is especially noteworthy, thus requiring some unpacking in relation to questions of temporality and the rhetorical figures of life and death so dear to both Kahn and Brunhes.

As Rosen notes, ruinous buildings were favourite objects of contemplation in nineteenth-century culture because they were deemed to crystallise in their very structure the 'sheer continuousness of the passage of time', hence the common recourse to romantic, organic metaphors to characterise those buildings as indeed 'living' in time. ${ }^{84}$ This idea is perhaps best exemplified in Georg Simmel's famous 1911 essay 'The Ruin', which he defines as 'the site of life from which life has departed'. Simmel adds: 'In the case of the ruin, the fact that life with its wealth and its changes once dwelled here constitutes an immediately perceived present'. ${ }^{85}$ This statement, in turn, resonates with Bazin's aforementioned concept of 'change mummified', as noted by Johannes von Moltke in relation to what he theorises as 'cinema's and the ruin's common function to visualize time and history in modernity'. ${ }^{86}$

During the war, however, the Kahn Archive mostly produced still rather than moving images of ruins. Moreover, when it comes to these autochromes of bombed-out towns there is a further difference related to the fact that they are not the product of the slow passage of time privileged by nineteenth-century romanticism or even Brunhes's own geographical interest in 'perishable forms' discussed earlier. Rather, they are evidence of an event that had produced a radical disjuncture in the course of time. For Simmel, ruins derive their aesthetic pleasure and epistemological appeal from the fact 'that here the work of man appears to us entirely as a product of nature', much like the 'forces which give a mountain its shape through weathering, erosion, faulting'. ${ }^{8}$ By contrast, the ruination obsessively documented in the Kahn autochromes cannot be dissociated from human engineering and the industrial barrage of artillery, thus making it less akin to the workings of time on geographical forms and more in tandem with the

83 See Mendibil, 'À la recherche de l'effet Brunhes', 130-139.

84 Rosen, Change Mummified, 50.

85 Georg Simmel, 'Two Essays', The Hudson Review, 11:3 (1958): 371-385; 384-385.

86 Johannes von Moltke, 'Ruin Cinema' in Julia Hell and Andreas Schönle (eds.) Ruins of Modernity (Durham, NC, and London: Duke University Press, 2010), 395-417; 396.

87 Simmel, 'Two Essays', 381. 
type of 'destructive economy' outlined by Brunhes. ${ }^{88}$ And indeed, Kahn's war collection holds such crucial historical importance today because it comprises the first wide-ranging documentation of a mode of destruction the scale of which had never been catalogued or experienced before. Here, Simmel's definition of the ruin thus necessitates a qualifier in the form of an adverb: it is the site of life from which life has abruptly departed.

Yet this does not mean that these images are removed from the aesthetic fascination historically identified with ruin gazing. ${ }^{89}$ Indeed, as Julia Hell and Andreas Schönle note, via Benjamin, as much as ruins 'invite reflections about history: about the nature of the event, the meaning of the past for the present', the 'aestheticization of ruins is unavoidable..${ }^{\circ}$ Beautifully framed and symmetrically arranged, these are remarkable images of evacuated towns and empty streets where houses, buildings, churches and shops have become material vestiges of their former selves: roofless skeletons, windowless façades, sheer rubble (A4841 and $\mathrm{A}_{5408)}$. Human presence is conspicuous by its absence, as in the many wooden carts unattended in the middle of streets and presumably left behind, a recurrent visual motif denoting rushed departures $\cdot{ }^{91}$ Of course, the photographers may well have arranged objects in the same way that the absence of human figures was sometimes an aesthetic choice. An example is a couple of near-identical autochromes of a wrecked house in the commune of Crévic, taken by Georges Chevalier in 1915, with the only difference between the two pictures being that one features its likely dwellers sitting on a pile of rubble in the foreground (Aoo5361) and the other no humans (A073109). But human evacuation was also a reality, for thousands of civilians had indeed died or fled the German offensive, an example being the town of Reims, where only 14,00o inhabitants remained out of 120,000 and whose near-obliteration was documented by Cuville and Castelnau in 1917.

Whatever political, aesthetic or propaganda purposes these human-free autochromes served, they therefore also need to be understood in relation to Kahn's concern that 'for the first time, all of humanity, at the same time, is threatened with the same fate'. Initially conceived as a 'record of humanity captured in the midst of life at the dawn of the twentieth century', during

88 As also noted by François Amy de la Bretèque, 'Les Archives de la Planète "Régions Dévastées", un regard humaniste et sa place dans l'histoire du cinéma' in Un monde et son double, 235-248; 245 .

89 See, in this respect, Brian Dillon, Ruin Lust: Artists' Fascination with Ruins, from Turner to the Present Day (London: Tate Publishing, 2014), 5-12

90 Julia Hell and Andreas Schönle, 'Introduction' in Ruins of Modernity, 1-14; 1.

91 See, for example, Aoo4797; A005309; Aoo5366 in the online catalogue. 
the war the Archives de la Planète becomes a visual laboratory of what a world without humanity might look like. ${ }^{92}$ As Amad has noted, the war violently reminded Kahn of the 'unpredictability of the present', lending 'an even more apocalyptic urgency' to his archival project..$^{93}$ Though Kahn unequivocally attributed responsibility to the Germans in his pamphlet, his idea of a supranational 'world union' was also meant to counter what he called the forces of 'arbitrariness and chance', which could potentially erupt and endanger the prospect of planetary peace. ${ }^{94}$

Kahn's anxiety over these forces is in tune with modern notions of temporality according to which time is always already change, instability, disorder: whether a continuously gradual or a brutally unexpected one. As Mary Ann Doane observes, 'modernity is [...] strongly associated with epistemologies that valorize the contingent, the ephemeral, chance', which become complex sites of pleasure and anxiety, since "[c]hange becomes synonymous with "newness," which, in its turn, is equated with difference and rupture'.95 The centrality of WWI ruins in the Kahn Archive cannot be dissociated from this conception of historical rupture and attendant notions of time as an unceasingly differentiating and potentially disordering force, especially when we consider that the ruins were occasioned not by natural processes but modern industrial warfare.

This fascination with ruins persisted in the Kahn Archive until its end, with Lucien Le Saint and Camille Sauvageot intermittently recruited to film and photograph the extent of war destruction on French soil and the reconstruction until the early 1930s. In 1922, Sauvageot was dispatched to Turkey with Frédéric Gadmer to register the harrowing aftermath of the Greco-Turkish war and the Great Fire of Smyrna, which extinguished much of the port city and forcibly expelled thousands of Greeks and Armenians. As with the WWI collection, the resulting films and autochromes depict a quasi-lunar landscape of demolition and dispossession. In the 5-minute film Casaba et Smyrne (Casaba and Smyrne, AI90577), for example, the utterly destroyed city of Smyrna is recorded in circular pans, with the odd human figure or dog glimpsed amid the rubble. Similarly, in the hundreds of autochromes taken by Gadmer, human presence is often nowhere to be seen and the impression is that of a world after the apocalypse, as in the striking

92 Brunhes, 'Ethnographie et Géographie humaine', 38.

93 Amad, Counter-Archive, 149, 200.

94 Kahn, Des droits, 9.

95 Mary Ann Doane, The Emergence of Cinematic Time (Cambridge, MA, and London: Harvard University Press), 20. 
picture of a derailed train standing diagonally over a destroyed railroad bridge, following on from the Greek Army's retreat from Turkey (A037214).

These images of human-induced destruction acquire further significance when placed in relation to those of natural phenomena and calamities in the Kahn Archive. In some respects, the presence of the latter can be attributed to Brunhes's human geography, one of the pillars of which, as we saw earlier, was the reciprocal relationship between human activity and nature. Although ethnographic matters did get the upper hand over more properly geographical ones in the Archive, soon after his appointment in 1912 Brunhes trained a camera operator to record geographical phenomena, while dispatching his student Cesare Calciati to an excursion across the US organised by the American Geographical Society, with two resulting films depicting geysers in action in the Yellowstone National Park and the Niagara Falls. ${ }^{96}$

Yet even before Brunhes the Archives had already showed a propensity for natural disturbances. One needs only consider the 1906 San Francisco earthquake ruins extensively photographed by Albert Dutertre during his trip with Kahn. Just as remarkably, the very first film catalogued in Kahn's Archive in 1910, titled Inondations des quais devant la Cercle Autour du Monde (Flooding of Docks Outside the Autour du Monde Society, AI48261), records in an unbroken shot the Autour du Monde members leaving Kahn's mansion on small boats, because the Seine had overflowed. In turn, this film makes a companion to the longer, nine-minute Inondations (Floods, AI 48953), filmed by Léon or Dutertre in that same year. Inondations documents the floods in the wider Boulogne region, complete with shots of crammed chariots and carts wheeling through the water, small boats coming and going, and agglomerations in critically flooded areas. Floods in Paris and surrounding regions also appear in many films produced for the Archive, as do glaciers. One film, shot in 1924 by Sauvageot and titled Crue de la Seine (The Seine Flood, AI48955), begins with the remarkable shot of lampposts almost entirely submerged in water.

Natural disasters are equally the topic of a select number of actualities acquired by Kahn, many from Gaumont, namely: Tremblement de terre (Earthquake, AI93248), filmed in Santa Barbara, US; Tremblement de terre sur l'île de Shikoku (Earthquake in Shikoku, AI12613), in Japan; La Ville détruite par le cyclone (The Cyclone-Ravaged City, AI93244), in Miami, US; Eruption du Mauna-Loa (Mauna-Loa Eruption, AI93255), in Hawaii; and

96 Valérie Perlès, 'La création d'un corpus filmique inédit aux origines des Archives de la Planète' in Les Archives de la Planète, 102-115; 108. 
Eruption de l'Etna (Mount Etna Eruption, AI45301), in Italy. Unlike the Kahn films, these are highly edited and short, and yet they are similarly intent on showing wreckage in the wake of natural catastrophes - and in the case of the Eruption du Mauna-Loa, shots of the eruption itself, with smoke and fire dominating the screen. Over a span of 20 years, the Archive acquired 31 films from Gaumont and other French film companies, many depicting landmark ceremonies and festivities. ${ }^{97}$ The percentage of acquired films of natural disaster is therefore not irrelevant, and when viewed alongside the films shot in Paris, they evince Kahn's concern with archiving the intrusion of the natural world into the human world by way of the unexpected, calamitous event.

Taken together, these films are in some measure indicative of what Nigel Clark has recently theorised as the 'inhuman nature' of our 'dynamic planet', or what he calls 'the earth's eventfulness', that is, the idea that 'instability and upheaval, rhythmical movement and dramatic changes of state are ordinary aspects of the earth's own history'.$^{8}$ Covering an array of meteorological, climactic and geological instabilities in a number of geographical regions across the globe, these films ask us to reconsider the Kahn Archive's construction of planetarity beyond the sociopolitical and the everyday and in terms of the Earth's physical agency and disruption. That is, if the war images attested to the human destruction of the world, these filmic records of floods, glaciers, volcanic eruptions, tornados and earthquakes show that the planet of the Archives de la Planète also acted of its own volition and bit back.

Seen in this light, Dutertre's stereographs of the San Francisco earthquake ruins are significant not only because they are the very first visual documents to enter the Kahn Archive, but also because of the importance which that natural event acquired by means of the novelty associated with its recording and subsequent dissemination worldwide. As Stephen Morgan notes: 'San Francisco 1906 was undoubtedly the first major disaster to be widely photographed by amateurs, but it was also the first to gain widespread coverage through the moving image'. ${ }^{99}$ Whereas far deadlier natural catastrophes had shaken the world before, destruction was often relayed by words, not the mediums of photography and film, the indexical

97 Jacques Siracusa, 'Les Archives de la Planète et Gaumont actualités: Les Écarts par rapport à la norme commerciale', Les Archives de la Planète, 324-325.

98 Nigel Clark, Inhuman Nature: Sociable Life on a Dynamic Planet (London: Sage, 2011), xi.

99 Stephen Morgan, 'A Tale of Two Cities: San Francisco 1906 and Earthquake in Adelaide' in Alan Wright (ed.) Film on the Faultline (Bristol and Chicago: Intellect, 2015), 21-45; 23. 
dimension of which promised a previously unthinkable sense of 'being there'. Unsurprisingly, as Kahn's acquired actualities attest, natural catastrophes became a favourite theme in early cinema as they forcefully testified to the medium's ability to capture the ushering forth of the unexpected and its aftermath. In other words, these early films of disaster evince an obsession with recording the intrusion of difference into the fabric of daily life, the rupturing moment that seismically disorders a world, leaving ruins in its wake. Kahn's produced and acquired films of natural disturbance, together with the Archive's sustained focus on human-driven destruction, participate in this fascination to register the moment in which the ordinary is suddenly, sometimes literally, inundated with extraordinariness.

\section{A Nonhuman Planet}

To consider the Archives de la Planète and human geography in the anachronistic light of the Anthropocene helps us see the way in which both projects - one a multimedia archive supported by a finance trader, the other a newly established academic discipline - conceived of the indeterminate ways of the world as it presented itself in the first decades of the twentieth century. As I hope to have shown, change, transformation, disorder and disruption are essential categories for an understanding of Kahn's Archive, the resulting planetarity of which, like that of human geography, postulated a dynamic and sometimes unpredictable interaction between the human and the nonhuman. This is not to say that Kahn or Brunhes articulated an 'Anthropocenic' vision of the world, since, as noted earlier, the Anthropocene presupposes the idea of a human-induced geological intervention whose environmental disturbances are unprecedented and relatively new according to a number of scientific measures and criteria. But it is to say that, as a project, the Archives de la Planète both mirrored and reflected on the precarity of social and natural worlds in the context of a global modernity whose effects were also the cause of fear and anxiety. While invoking concepts of variability, mutability and evanescence, the ruins in Kahn's Archive seem also to embody his fear that the war could wipe humanity off the face of the planet: 'the storm that shaking the Earth touches every living being. ${ }^{100}$

However, as much as Kahn conveyed in words the fear of such a fate, and as much as the numerous images of ruins in his Archive allow us a momentary glimpse into a world bereft of humans, the Archives de la 
Planète remained human-centric when not ethnocentric. After the end of the war, Sauvageot and Le Saint travelled through France to record its ruins on film and, shortly after, the reconstruction. Variously catalogued as régions dévastées (destroyed regions), régions libérées (freed regions) and villes reconstruites (reconstructed cities), these films and autochromes unequivocally subscribe to patriotism in their documentation of national restoration, including the resumption of human life in extraordinary times.

Thus, in the remarkable three-part series En dirigeable sur les champs de bataille (Airship over the Battlefield, 1919), the ever-moving aerial perspective over the Western front surveys the staggering scale of the destruction while capturing from high above diminutive human figures going about their business amid the wreckage. In La ville en ruines (City in Ruins, AI107664), also shot in 1919, ground-level panoramas scanning the dilacerated commune of Albert allow the unprogrammed intrusion, in its penultimate shot, of a single man pushing a cart traversing the rubble. Though autochromes were also utilised in the immediate aftermath of the war, the properties of film heightened the reawakening of human life in cities as people went about through the wreckage, their movement reinscribing vitality amid dead matter.

Above all, the Kahn Archive is human-centric in that it presupposed a human spectator in the future. Today, Kahn's autochromes are now available in digitised form on our computer interfaces, a turning public of the Archive that comes to fulfill Brunhes's prophecy that it is 'for those who will come after us'. ${ }^{101}$ Yet to say that Kahn's images were manufactured with humans in mind may sound redundant, even pointless: aren't mechanically recorded images always produced for and by humans?

Some contemporary projects - including the film Homo Sapiens (2016) and the photographic project The Last Pictures (2012), discussed below - have attempted to complicate a straightforward answer to this question, no doubt as a response to a widespread sense of precarity fuelled by unrelenting sociopolitical, economic and ecological turbulences. As in the Archives de la Planète, the driving forces behind these projects are fear of disappearance and anxieties over the passing of time. Unlike Kahn's Archive, they envision the worldhood of the world after humanity; the life they depict and/or imagine is of a nonhuman, sometimes extraterrestrial nature, even if they simultaneously make recourse to contemporary ruination and anticipate a human spectator in the present. By 'imaging and imagining a certain future "after the human" from the viewpoint of the here and now', to cite 
Joanna Zylinska, some of these projects must be therefore viewed as more than so-called 'ruin porn', since their visual power is located not in mere aestheticisation but in a temporal forking that attempts to 'reimagine our relation to the world just before the ruin.' ${ }^{102}$

Consider briefly Tong Lam's photobook Abandoned Futures: A Journey to the Posthuman World (2013), which defines itself as a 'global overview of [...] decay and abandonment'. Compiling images recorded in Japan, China and the US, among other countries, Lam justifies his focus on ruination as a march against time. Unlike ancient ruins, which 'deteriorate solemnly over centuries', their industrial and postindustrial counterparts have been abandoned or discarded in decades if not years. The alarming rate at which ruination proliferates makes it plausible to infer that 'there will be a time when ruins and wastelands begin to outnumber functioning spaces'. Lam concludes: 'globally, there are probably already more ruins created in the first decade of the Twenty First century alone than in the entire Twentieth century. Time, in short, is speeding up exponentially'. ${ }^{103}$ Yet if Abandoned Futures testifies to an urgency to record disappearance, it equally proposes, as per its oxymoronic title, to use indexical records of the now as a means of envisioning and reflecting on what a world without humanity looks like.

Something similar happens in Homo Sapiens, by Nikolaus Geyrhalter. Inspired by Alain Weisman's bestseller The World without Us (2008), which starts from the premise of a 'world from which we all suddenly vanished', Homo Sapiens compiles durational shots of ruinous sites recorded in many corners of the world, many of which are featured in Abandoned Futures and possibly recognisable to the viewer. ${ }^{104}$ These include the Buzludzha monument in Bulgaria, which bookends the film; the abandoned building blocks in the Hashima Island and the streets of Fukushima in Japan; and the postindustrial cityscape of Detroit in the US. For all intents and purposes, then, Homo Sapiens is a documentation of worldwide ruination authenticated through indexical imagery, which situates the film in the present and provokes thought on the world as ravaged by unchecked progress. Wars, consumerism, natural disasters, communism and capitalism - all are haunting absences 'living' in the film's decaying structures.

102 Joanna Zylinska, Nonhuman Photography (Cambridge, MA, and London: MIT Press, 2016), 85,89 . On ruin porn, see Dora Apel, Beautiful Terrible Ruins: Detroit and the Anxiety of Decline (New Brunswick, NJ, and London: Rutgers University Press, 2015).

103 All citations in this paragraph are from Tong Lam, Abandoned Futures: A Journey to the Posthuman World (Carpet Bombing Culture, 2013). The book is not paginated.

104 Weisman, The World without Us, 4. 
Further, the film's protracted inspection of ruinous sites, with their unexpected arrangements of living and nonliving matter, capitalises on the excessive, uncanny materiality of such places, with their disorderly combination of the strange and the familiar. At one point in the film, for example, we see the remnants of a bar as though going through a process of mutation, with the stools lined along the counter covered with green mould. Another shot shows an oversized plant in a vase inside an abandoned office, the gigantic branches growing on both sides reminding the viewer of the plant's will to live. As Tim Ederson argues, to encounter a world in ruins is to attend to the heightened and hybrid physicality of a new ontology of things:

Things in ruins [...] are charged with a more radical alterity. Lacking any obvious meaning, feeling different, unclear in their function, aesthetically indecipherable and out of place, these artefacts pose an alternative way of relating to objects that goes beyond buying and possessing them, domestically displaying and enfolding them, and using them as common-sense fixtures around which everyday life is organised. ${ }^{105}$

In Homo Sapiens this is reinforced in shots that show objects in unexpected places or juxtapositions, such as a boat in a field (figure 6.2), a giant teddy bear collapsed on the floor in an abandoned theme park (figure 6.3), a car inside a cave illuminated by a beam of sunlight, and a rollercoaster on the seashore partly submerged in water (figure 6.4). In their surrealist but indexically certified figurations, these images recall some of Kahn's autochromes, including the striking image of a train standing diagonally on railway tracks in Turkey after the Greco-Turkish war discussed earlier. Although the implication that the director may have tampered with reality to achieve some of these juxtapositions cannot be discounted, they call attention to the evidentiary properties of the image by highlighting the unexpected as resulting from natural calamities and the Earth's eventfulness: indeed, the rollercoaster was in reality pushed into the sea by Hurricane Sandy, in Seaside Heights, New Jersey.

Yet because there is no recourse here to conventional staples of the documentary mode - written titles, interviews, talking heads or voiceovers - Homo Sapiens, like The World without Us, must also be viewed as a post-apocalyptic fable. This reading is substantiated when we consider the temporal ordering of shots, which imparts a sense of narrative progression whereby the Earth, as a planet endowed with agency and volition, seems 

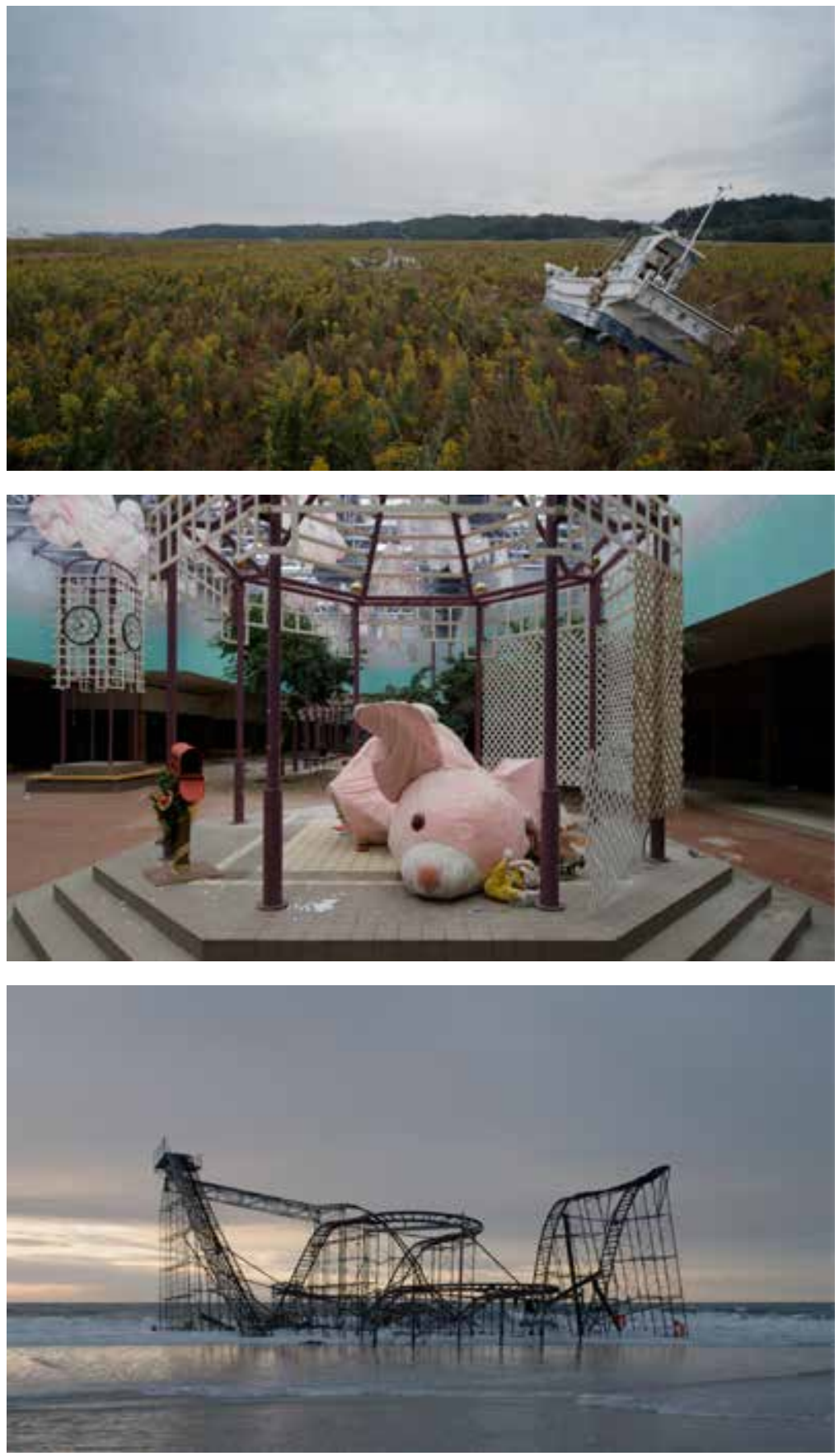

Figures 6.2, 6.3 \& 6.4 Surrealist but all-too-real juxtapositions in Homo Sapiens, some of which, as in the image of a rollercoaster pushed into the sea by Hurricane Sandy, are the result of natural disasters. Courtesy of NGF. 
to gradually reclaim its formerly occupied surface over an unspecified period of time. Whereas Homo Sapiens starts with short-distance images of human figures inscribed in the tiled walls of the Buzludzha monument and then proceeds in its first hour to show the inside of buildings - a cinema, an office, a hospital, a church, a dance club and so on - the film's last 30 minutes gesture towards a more complete planetary takeover. This is conveyed through outdoor shots in which the signs of 'civilisation' become less prominent, with some images displaying houses and buildings almost entirely submerged in sand and snow. The film's closing shot is telling in this context, for it goes back to the Buzludzha monument, which is now recorded from outside, engulfed in winter fog. Gradually the screen turns white, implying a sense of closure to this process of repossession - as if humanity was nothing but an interlude in the planet's temporal itinerary, with the Earth, now freed of humans and human signs, carrying on its business as usual.

Such a futurocentric outlook may raise suspicions in its seeming postulation of an inevitable fate against which human action is futile. Donna Haraway warns us: 'There is a fine line between acknowledging the extent and seriousness of the troubles and succumbing to abstract futurism and [...] its politics of sublime indifference.'. ${ }^{106}$ Yet to 'learn to be truly present', to follow Haraway's call, also requires adjustments to the differing space-time frameworks that the global environmental crisis has dramatically jumbled up. ${ }^{107}$ This includes a reckoning with the intrusion of geohistory into human history, which Dipesh Chakrabarty has described (not coincidentally in relation to Weisman's The World without Us) as 'a universal that arises from a shared sense of catastrophe'. ${ }^{108}$ In any case, Homo Sapiens is no 'abstract futurism' or even a thought experiment, as the book by which it was inspired defines itself. It is instead a record of the concrete world that simultaneously visualises its possible future. In other words, the film documents an imaginary situation that is embedded in present-day reality; its world-without-us is one that sends us back to this world.

That Geyrhalter is concerned with registering a changing world comes as no surprise: his films are often keenly interested in documenting the effects of globalisation in terms of its socio-cultural, political, technological and environmental effects across the planet. Of particular relevance here is

106 Donna Haraway, Staying with the Trouble: Making Kin in the Chthulucene (Durham, NC, and London: Duke University Press, 2016), 4, 2.

107 Ibid., 1.

108 Chakrabarty, 'The Climate of History', 222. 
one of his most ambitious projects, the four-hour globe-trotting Elsewhere (2001), conceived as a world catalogue of remote cultures living at the dawn of the new millennium. It is worth quoting in full Geyrhalter's rationale for this project:

We thought this special year would be a good opportunity to travel around and see how the world was changing. We knew that many traditions around the world were in what seemed to be their final stages, so we decided to search for instances of the changes that were taking place. I assumed that the film would be shown at festivals and in cinemas, but most of all I had the feeling that I was doing this film for the human archive. In a hundred years I think Elsewhere will be valuable as a mapping of the state of the world during this specific year. ${ }^{109}$

It would be no exaggeration to say that Geyrhalter's words reproduce almost ipsis litteris the justification for the Archives de la Planète over a hundred years ago. Like Kahn and Brunhes, Geyrhalter attributes his urgency to document to global modernity's wiping out of traditional localisms. He conceives of film as a suitable medium to preserve the state of the world as inhabited by humans at the beginning of a new century (and millennium). And he validates the significance of his project in terms of its storage of the world for 'the human archive' in the future.

In turn, Geyrhalter's projecting of Elsewhere into the far ahead makes us reassess Homo Sapiens, released 15 years later. While doubtless also made to be 'shown at festivals and in cinemas', and therefore for a present-day human viewership, we would be perhaps forgiven for speculating whether Homo Sapiens was produced with 'the human archive' in mind, in which case it would function, like Elsewhere, as a global catalogue of ruinous sites recorded in the first decades of the new millennium; or whether it instead presupposes, as conveyed by its visual content, that in a hundred years' time, such an archive may prove pointless in view of the non-existence of humanity, in which case it begs the question to whom exactly these images would be of service. Significantly, this oscillation between the human and the nonhuman is mapped on to the film's formal carapace and visual design.

On the one hand, despite its title, there are no humans in Homo Sapiens. If this is a film that speaks to 'the possibility of life in capitalist ruins', to cite the title of Tsing's book, these are not the people emerging from the 
skeleton towns of Kahn's films. The focus here, rather, is on nonhuman animals, forces, elements and entities: mould, vegetation, birds, insects, frogs, rain, snow, sand, and especially the wind. In fact, Geyrhalter even used leaf blowers in some scenes so as to inject a sense of motion, with the wind moving things as it moves about. One could go so far as to say that Homo Sapiens grants a new lease of life to 'the wind in the trees' that presumably enthralled early film spectators - but now there are no humans in the image feeding a baby and the wind blows discarded, humanmade things: bird cages, plastic bags, book pages, strips of paper. ${ }^{110}$

On the other hand, the human is a negative principle around which Homo Sapiens worlds its world. The majority of the film is devoted to recording dilapidated institutions, buildings and artefacts where humans are conspicuous by their absence. At the same time, the human is a spectre that haunts the film's poised machinic gaze, with stationary images featuring Geyrhalter's signature geometric shots, achieved through symmetric compositions and wide-angle lenses (figures 6.5 and 6.6). This produces a perspectival regime of vision that continually underlines the centrality of the human eye to which these images are directed, recalling Jean-Louis Baudry's assertion that the camera internalises and 'specifies the position of the "subject", the very spot it must necessarily occupy'. ${ }^{111}$

The film's vision, however, remains that of a machine: its assertion of the camera's mechanical eye constructs an ocular regime that implies in the structure of the image a human subject but never fully morphs into a human perspective. Could we therefore assume that this is a camera miraculously recording the world after we are gone? If so, Homo Sapiens invites some reflections on cinematic automatism as espoused by André Bazin and Stanley Cavell.

Bazin famously writes in his 'Ontology' essay, originally published in 1945: 'For the first time, between the originating object and its reproduction there intervenes only the instrumentality of a nonliving agent. For the first time an image of the world is formed automatically, without the

110 As the story goes, when confronted with one of Auguste and Louis Lumière's first films, Le repas de bébé (1895), audiences were more interested in the blowing leaves behind the eponymous baby and its feeding parents. Decades later, in 1944, D. W. Griffith claimed on his deathbed that films lacked the 'beauty of the moving wind in the trees'. See Nico Baumbach, 'Nature Caught in the Act: On the Transformation of an Idea of Art in Early Cinema' in Jeffrey Geiger and Karin Littau (eds.) Cinematicity in Media History (Edinburgh: Edinburgh University Press, 2013); 107-116; 107.

111 Jean-Louis Baudry, 'The Ideological Effects of the Basic Cinematographic Apparatus', Film Quarterly 28:2 (1974): 39-47; 41. 

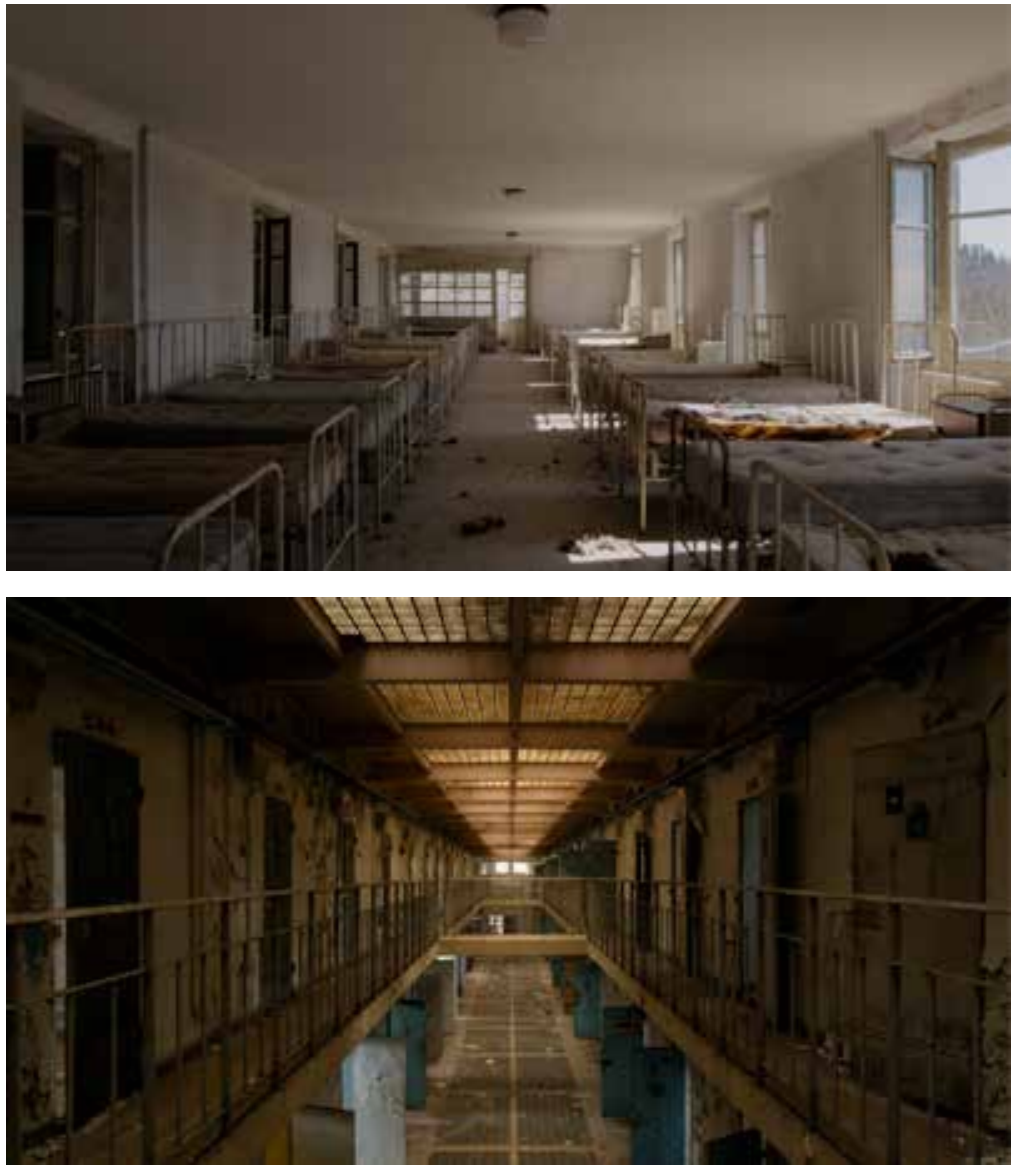

Figures 6.5 \& 6.6 Ultra-perspectival images in Homo Sapiens underline the human eye to which they are directed. Courtesy of NGF.

creative intervention of man'. ${ }^{112}$ Inspired by Bazin, Cavell similarly marvels at the fact that photography 'does not present us with "likeness" of things; it presents us, we want to say, with the things themselves'. ${ }^{113}$ Ultimately the only certainty we have about photographs is that they 'are not hand-made; they are manufactured. And what is manufactured is an image of the world' ${ }^{114}$ By eliminating the human agent, Cavell concludes, photography 'overcame subjectivity', so much so that it 'maintains the presentness of the world by

112 Bazin, What is Cinema?, 13, my emphasis.

113 Stanley Cavell, The World Viewed:Reflections on the Ontology of Film (Cambridge, MA, and London: Harvard University Press, 1979), 17.

114 Ibid., 20, my emphasis. 
accepting our absence from it'. ${ }^{115}$ For both thinkers it is therefore imperative to consider the ontology of photography - and consequently cinema - as resulting from an automatic process whereby it is the world that presents itself to the camera and gives itself to be viewed. In this sense, not only is their thought still relevant to the digital capture of reality (as in Homo Sapiens), it also endows the world with a sense of agency and intentionality in the forming of its own image.

Now, this is certainly not an all-seeing vision of the world. Indeed, if Bazin defines the 'myth of total cinema' in terms of a desire to achieve a complete reproduction of reality - an 'integral realism, a recreation of the world in its own image, an image unburdened by the freedom of interpretation of the artist and the irreversibility of time' - such an idea, in its dream of totality, remains a myth given the technical limitations of cinema and the fact that there are always subjective elements in the image. ${ }^{116}$ That said, for both Bazin and Cavell, it is the world itself that shapes its own image for the camera, and in this sense, the image does imply a totality of the world that is left out of the picture. As Cavell notes, unlike painting, 'a photograph is of the world', since 'the implied presence of the rest of the world, and its explicit rejection, are as essential in the experience of a photograph as what it explicitly presents. A camera [...] holding on an object is holding the rest of the world away'. ${ }^{17}$

No doubt both thinkers championed the cinema in relation to its values and benefits for a human subject and therefore as a phenomenology: in Bazin a subject in fear of the inexorability of time and who finds in cinema's reproduction of duration - its capacity to 'mummify' change, as we saw earlier - a way of deferring anxiety about death; in Cavell a subject whose consciousness has been unhinged from the world and who finds solace in the cinema precisely because cinema mechanically seals this unhinging 'through no fault of my subjectivity'. ${ }^{118}$ But if Bazin and Cavell assessed the cinema in relation to a human viewer, it was because cinematic images of the world are not subjectively formed; cinema is valuable not so much because it allows us to see the world in different ways but because it allows the world to reveal itself in its own terms for a nonhuman entity: the camera.

Homo Sapiens resonates with these ideas and reflections. It does so, first, through its fictional universe, which manufactures the world as a world in

115 Ibid., 23.

116 Bazin, What is Cinema?, 21.

117 Cavell, The World Viewed, 24.

118 On Bazin's phenomenological subject, see Rosen, Change Mummified, 3-41; Cavell, The World Viewed, 23. 
which only the world, without humans, exists. And, second, because this is a world that makes itself available in visual form through the lens aperture of film cameras whose perspectival vision, in its turn, reminds us of the role cinema once played by and for humans in an unspecified past. In other words, Homo Sapiens reduces a Bazinian-Cavellian ontology of cinema to its most fundamental principle by imagining a scenario that strips down the automatic process of cinema to the world-in-itself (the producer of images) and nonhuman film cameras (the recipient of images), while at the same time highlighting in the composition of the image the significance of cinema for humanity.

The uncanny mode of spectatorship the film promotes is therefore tied to the epistemologically restless recognition that, as viewers, we are not simply witness to a world without us but, rather, to a world that produces its own images, on its own, without us. In so doing, the film raises questions concerning the use and archiving of indexical images after humanity is no more. To put it bluntly: would other nonhuman entities, terrestrial or extraterrestrial, be able to discern, understand and perhaps be moved by images of our planet after we are gone?

\section{A Non-Planet}

Outlandish as it may seem, this is one of the driving questions of Trevor Paglen's The Last Pictures project, which he developed in partnership with the public arts organisation Creative Time and the satellite company EchoStar Corporation. With a creative team, Paglen selected 100 illustrations - most of them photographs - that are meant to act as a visual memento of a global humanity before its perishing. The images were etched onto a small silicon disk attached to the side of the satellite spacecraft EchoStar, which was launched in 2012 and will orbit around the Earth for at least billions of years or even indefinitely. Like Homo Sapiens, The Last Pictures is interested in the future in order to make people think about our planet now: whereas all efforts were made to ensure that the materials utilised in the archival disc would indeed last for billions of years, Paglen recognises that 'the idea someone in the future might actually find the Artifact was close to nil [...] but the probability of people on Earth thinking about it here and now was guaranteed. ${ }^{\prime 19}$ Thus, concomitant to the sending of the disk into

119 Trevor Paglen, The Last Pictures (New York, Berkeley, Los Angeles and London: Creative Time Books and University of California Press, 2012), 11-12. 
orbital space, The Last Pictures was turned into a publication containing Paglen's ideas, inspirations and the selected pictures, most accompanied by statements explaining the reason behind their inclusion in the project.

Like all works discussed in this chapter, The Last Pictures is the fruit of anxieties over what Paglen defines as modernity's 'continual speeding up of time', which has now begun to interfere with geological temporalities. He goes on: 'The Anthropocene is a period of temporal contradictions, a period in which Marx's space-time annihilation chafes against the deep time of the earth'. ${ }^{120}$ Tellingly, the opening image in the collection is a photograph of the back of Paul Klee's Angelus Novus (1920), with labels from the Israel Museum (Jerusalem) and the Museum of Contemporary Art (Chicago). As explained in the book's contextual note, the picture is an allusion to Benjamin's famous reflection on the monoprint as the 'angel of history', one that sees history as 'one single catastrophe, which keeps piling wreckage upon wreckage.' ${ }^{121}$

Many of the subsequent, sometimes iconic, images subscribe to this idea, offering glimpses into stories of human conquest, transformation but especially destruction of the world. They depict wars, the space age, extractivism, deforestation, surveillance, animal cruelty, epidemics, consumerism, nuclear power and biogenetics. At the same time, the trope of the ruin reappears, though it is no longer connected with terrestrial wastelands but set in relation to orbiting satellites, which are defined by Paglen as 'the cultural and material ruins of the late twentieth and early twenty-first century'; 'destined to remain in Earth orbit until Earth is no more' and thus 'far outlast anything else humans have created. ${ }^{122}$ Space junk becomes the final, ceaselessly floating wreckage piled upon a Benjaminian history.

As Paglen is quick to point out, the collection was never designed as 'a grand representation of humanity' or 'a portrait of life on earth', but rather, as the proof of how and why things went wrong down on terrestrial soil. ${ }^{123}$ Three different images allude to the failure of the universal language project: a page of a dictionary of Volapük, hailed at the end of the nineteenth century as a 'world speak'; a detail of Pieter Bruegel's Tower of Babel painting (1563); and a page of John Wilkins's 1668 An Essay Towards a Real Character and a Philosophical Language, considered one of the first attempts to develop a universal language. A pair of successive pictures, the only ones depicting

120 Ibid., xii.

121 Benjamin, Illuminations, 12.

122 Paglen, The Last Pictures, 11.

123 Ibid., 11. 
exactly the same place from the same angle, tells a story of disappearance in the age of the Anthropocene, showing the before and after of Grinnell Glacier in Glacier National Park, Montana, in 1940 and 2006 respectively, with the glacier in the latter picture entirely melted.

But disappearance appears in the project in another, perhaps even more significant guise: a disappearing world of images. Crucial for the execution of The Last Pictures was finding the right home, materials and shape for its archiving gold disk so that it would survive the fullness of time. Whereas the disk was housed in a satellite that will cease functioning 15 years after its launch, the spacecraft will remain in space, among hundreds of satellites, for potentially billions of years thanks to the timeless stability of the orbit in which it finds itself: the geostationary orbit (GSO), or Clarke Belt. Though we now produce trillions and trillions of images, most of which are transmitted across the surface of the globe by these very satellites, such images are ultimately evanescent and fleeting as material objects when examined from the perspective of cosmic time. As Sean Cubitt notes in his Finite Media:

Media are finite, in the sense both that, as matter, they are inevitably tied to physics, especially the dimension of time; and that their constituent elements - matter and energy, information and entropy, time and space, but especially the first pair - are finite resources in the closed system of the planet Earth. Because they are finite, media not only cannot persist forever; they cannot proliferate without bounds. ${ }^{124}$

The Last Pictures must be viewed in the context of this problematic. To cite Paglen himself: 'One of the technical problems I was trying to solve was that of archivability: what materials and techniques exist, if any, to produce an "ultra-archival" medium for storing images'? ${ }^{125}$

When placed next to that other archive we have explored in this chapter, the Archives de la Planète, The Last Pictures invites some reflections on questions relating to the finitude and materiality of images both in present and future times and terrestrial and cosmic worlds. As Cubitt goes on to note: 'When we speak of film as a "living medium", we should take the term literally', with its archival life defined by a struggle 'between the order of the archive and the entropy of what the archivist understands as decay, but which can also be understood as the evolution of a new artifact from the

124 Sean Cubitt, Finite Media: Environmental Implications of Digital Technologies (Durham, NC, and London: Duke University Press, 2017), 7.

125 Paglen, The Last Pictures, 17. 
old', with the artifact 'moving on through time, now and forever pinned to migration from format to format.'. ${ }^{26}$

A hundred years after its genesis, the Kahn Archive has already undergone momentous technological mutations in relation to how its images are archived, that is: handled, stored, formatted, catalogued, juxtaposed and visualised. Indeed, the majority of researchers visiting the Musée Albert-Kahn's facilities today will most likely have access not to the original autochrome plates and reels of celluloid film, but to the digitised version of these materials housed in the FAKIR database, with all the navigation tools and tags that comprise, structure and constrain any digital catalogue, as we explored in chapter 3. In a way, as Lundermo argues, the return of these images in digital form doubles down on the disappearance that provided the impetus for the Kahn Archive by alluding to the disappearance of its originary formats and supports:

The communities and people at the center of Kahn's archival project were on the brink of disappearance. The fleeting moments inscribed in the archive's films and autochromes were inhabited by ghosts and specters of a lost time [...] When this haunted archive returns in digital mode, it is a return of ghosts of ghosts. ${ }^{127}$

Although there is much debate concerning the unreliability of the digital as a vertiginously mutating format, the current digitisation of archives, as in the Kahn Archive, is meant to ensure that the images can be preserved for a longer time by sacrificing their original material bases. In other words, the digital appears as a precautionary measure to maximise the survival of original artefacts stored away from human contact, thus ensuring the continuance of their visual content in other formats - even if, of course, the digital also has a physical basis and will, too, be subject to decay.

For Bjorli and Jakobsen, the Archives de la Planète 'is a time capsule, designed to communicate with an unknown future.. ${ }^{128}$ Today this capsule finds itself materialised as digitised photographs on a computer interface. In some ways, The Last Pictures also conceives of itself as a time capsule, but where it differs from Kahn's Archive is that its future lies inconceivably ahead. As Janine Marchessault observes: 'In Paglen's project, the planet is

126 Cubitt, Finite Media, 2-3

127 Lundermo, 'The Archives of the Planet" and Montage', 222.

128 Bjorli and Jakobsen, 'Introduction' in Cosmopolitics of the Camera, 3. Amad makes the same point in Counter-Archive, 154 . 
no more. The time capsule communicates the end of the end - an Oblivion which is, at least in part, countered by the gesture of sending the satellite up into space to tell the diversity of stories that make up the end. ${ }^{129}$ This desire to tell the end of the end dictated not only the fabrication of a specific disk but also its location: a satellite that may outlive the Earth because of the space orbit's time-free properties when compared with planetary time. In this context, though infinitely more modest in scope and literally miniscule in its physical constitution, The Last Pictures nonetheless appears surprisingly more ambitious than Kahn's Archive in its quest to 'transcend the Anthropocene and [...] deep time itself' and 'theoretically last for an eternity'. ${ }^{130}$

Although we might be tempted to scoff at the loftiness of these statements, perhaps we should see them simply as the most hyperbolic expression of profound anxieties over the passing of time, anxieties which recording media have been recruited to assuage since their inception. But whereas the promise of the indexical image for the archive is the promise of a preservation of life for the future, neither the archive nor the image may ultimately sidestep the incessant force of continuance and variability that is time, one whose inalienable presage is the degradation of materials and realities of which archives, images and worlds are constituted. From this perspective, The Last Pictures merely radicalises the preservationism of the Archives de la Planète by locating photographs literally outside the Earth and beyond terrestrial time. Or, to put it differently, it sends its collection of images up into the dark abyss of interstellar space so as to archive the planet into infinity.

129 Janine Marchessault, Ecstatic Worlds: Media, Utopia, Ecologies (Cambridge, MA, and London: MIT Press, 2017), 246.

130 Paglen, The Last Pictures, xiii; 18. 